Open Access

\title{
Predicting minimum tillage adoption among smallholder farmers using micro- level and policy variables
}

\author{
Paswel P. Marenya ${ }^{1 *}$, Menale Kassie ${ }^{2}$, Moti Jaleta ${ }^{1}$, Dil Bahadur Rahut ${ }^{3}$ and Olaf Erenstein ${ }^{3}$
}

\author{
* Correspondence: \\ p.marenya@cgiar.org \\ ${ }^{1}$ International Maize and Wheat \\ Improvement Center (CIMMYT), P.O. \\ Box 5689, Addis Ababa, Ethiopia \\ Full list of author information is \\ available at the end of the article
}

\begin{abstract}
Minimum tillage combined with mulching (MTM) is critical to conservation agriculture, yet its use by smallholder farmers raises challenging questions regarding adoption, diffusion and scaling at farm level. In this paper, we used probit regression and post-estimation simulations to identify the key micro (farm specific) and macro (country specific) factors as predictors of MTM adoption in four countries spanning a north-south gradient in eastern and southern Africa (ESA): Ethiopia, Kenya, Tanzania and Malawi. We found that farmers' access to markets and social capital empirically predicted MTM adoption. Policies that increased fertilizer subsidies and extension-staff-to-farmer ratios had similar effects, even if only modestly. Conceivably, subsidies specifically targeted at MTM could also be considered based on their potential environmental and social benefits. We conclude that adoption of MTM still faces the same micro- and macro-level hurdles common to all agricultural technologies. Long-term investments in agricultural extension and reductions in the costs of complementary inputs are critical for the diffusion of MTM.
\end{abstract}

Keywords: Adoption, Agricultural extension, Conservation agriculture, Policy, Input subsidy

JEL classification: Q01, Q18, Q12

\section{Background Motivation}

Due to dwindling arable land and ongoing unfavourable climatic changes, the need for sustainable intensification of agriculture has gained considerable urgency (The Royal Society 2009). This has increased interest in climate-smart agriculture (CSA), redirecting agricultural development in ways that recognize the present realities of climate change (Lipper et al. 2014). FAO defines CSA as agriculture that sustainably increases productivity, enhances resilience (adaptation), reduces greenhouse gases (GHGs mitigation) where possible and enhances the achievement of national food security and development goals (FAO 2013). This context has generated a growing interest in conservation agriculture whose key agronomic principles are as follows: minimization of soil disturbance; continuous maintenance of soil cover; and crop diversification (by rotations, intercropping or other crop associations) among other practices.

(c) The Author(s). 2017 Open Access This article is distributed under the terms of the Creative Commons Attribution 4.0 International License (http://creativecommons.org/licenses/by/4.0/), which permits unrestricted use, distribution, and reproduction in any medium, provided you give appropriate credit to the original author(s) and the source, provide a link to the Creative Commons license, and indicate if changes were made. 
Conservation agriculture is thereby posited to conserve soils and in the long run to improve soil properties, conserve moisture, stabilize and even enhance crop yields (Hobbs et al. 2008; FAO 2012). The principles of resource conservation and the envisaged outcomes are consistent with the basic notions of CSA. Around the globe, the adoption of conservation agriculture has been successful on larger farms in Australia, Canada, the USA and Latin America-most notably Brazil and Argentina-whereas in Africa where some evidence of adoption has been offered, these have been largely modest when measured in terms of widespread diffusion, for example in Ghana, India, Pakistan and Bolivia (Ekboir 2010).

The productivity and environmental benefits of the minimum- and no-till aspects of conservation agriculture have been variously documented in the literature (Erenstein 2003; Hobbs 2007). Minimum tillage (or no-till) is a seedbed preparation method that involves minimizing the number of tillage operations by making only limited slots for placing the seed, either by using specialized machines (seeders) that open up small furrows in which seed is placed or by manually using 'jab planters', hoes or dip sticks to bore holes into which seeds are placed. In such cases, there is minimal soil disturbance since the rest of the field is left untilled. Mulching typically involves retaining crop residues and other plant materials on the surface of the plot to cover as much soil surface as possible. The mulch protects the soil from erosion, sun and wind, and the superficial biomass enhances infiltration and provides nutrition to the biota that aerate the soil. Erenstein (2003) enumerated the beneficial impacts of mulching on soil conservation, soil ecology, crop yields and the environment. If implemented properly, the combination of minimum tillage (or no-till) and mulching can alleviate or even halt soil erosion and lead to water conservation and reduced runoff, groundwater replenishment and enhancement of soil biota. In some cases, yield stabilization and increases have also been observed (Erenstein 1999, 2003).

Conservation agriculture for smallholder farmers raises challenging questions regarding its adoption, diffusion and scaling at farm level and beyond. The multiple component technologies that need to be applied simultaneously are one complicating factor. Here, we focus on the subset of minimum tillage combined with mulching (MTM). ${ }^{1}$ MTM is likely to face impediments to adoption associated with the inherent substitution of practices, e.g. seasonal labour scarcities for weeding, given that absence of herbicides can make weed-management more labour-demanding in minimum-tillage systems (Nyamangara et al. 2014). Other constraints relate to the opportunity cost of crop residues for feed rather than mulch (Pannell et al. 2014, Jaleta et al. 2013, 2015), and possible short term yield depression in the initial years of implementing no-till and mulching (Pannell et al. 2014). Smallholders often have short-term planning horizons due to high discount rates and are often unwilling to accept yield penalties for a few years to improve soil conditions and yields in later years (Pannell et al. 2014; Erenstein 2003).

\section{Objectives}

The objective of this paper is to examine the contribution of micro-level household and policy variables in conditioning the simultaneous adoption ${ }^{2}$ of two important conservation agriculture component technologies: minimum tillage combined with mulching (hereinafter, MTM). The first hypothesis we test is that MTM adoption is 
conditioned by the characteristics of the smallholder farm, particularly its demographic characteristics, plot characteristics and market and credit access. The second hypothesis is that MTM adoption is also conditioned by macro-level policy variables beyond the farm. We therefore include multiple countries (Ethiopia, Kenya, Malawi and Tanzania) so as to include country-level policy variables obtained from secondary sources: (1) extension personnel-to-farmer ratios (EFR) and (2) subsidy expenditure as a percentage of agricultural budgets spent on farm input subsidies (SER).

Based on the above micro- and macro-level variables, the contribution of this paper to the literature on MTM adoption is as follows:

1) The use of a multi-country dataset allows us to analyse the co-determinants of adoption of MTM across diverse environments. Much of the evidence in the literature is still based on localized cross-sectional surveys (Erenstein and Thorpe 2010; Hobbs 2007) and sometimes on extrapolations from these (Erenstein et al. 2012). The use of multi-country data that spans a north-south gradient in eastern and southern Africa enables us to present MTM adoption evidence from a regional perspective. The results from such a multi-country analysis can facilitate lesson sharing across countries and also sensitize the agricultural development community to the pitfalls of broad generalizations in terms of what works for MTM adoption. This multi-faceted approach is needed to help improve the external validity of adoption evidence on MTM specifically and on conservation agriculture ${ }^{3}$ more broadly.

2) This paper also helps answer an important outstanding question: based on its resource-conserving and cost-reduction advantages (labour and animal draft power) as reported in the literature, can MTM circumvent the adoption challenges faced by other agricultural innovations with regard to smallholders? To try to answer this question, we analyse the predictors of adoption using models that are similar in approach and hypothesis to those used in adoption studies generally.

3) We fill a notable gap in the literature concerning the need to analyse the adoption of component technologies involved in conservation agriculture beyond the micro-level. Some researchers, e.g. Knowler and Bradshaw (2007), have reported that whereas most of the conservation agriculture costs are incurred at the farm level, most of the environmental benefits transcend the farm boundary. This is a factor that brings conservation agriculture adoption into the orbit of policies designed to achieve sustainable agricultural production. Our contribution here is to demonstrate how the adoption of MTM can be predicted from the national-level policy environment.

The four study countries (Ethiopia, Kenya, Tanzania and Malawi) span a north-south gradient in eastern and southern Africa. They were purposively selected for this study and the overarching research-for-development project that collected the data used in this study. The project was implemented by the International Maize and Wheat Improvement Center in collaboration with national research partners in the four countries. The socioeconomic component of the project collected data based on household surveys intended for use in analysing socio-demographic factors that could be associated with adoption or non-adoption of conservation agriculture-based practices such as MTM. 
The rest of this paper is organized as follows: the rest of the introductory section outlines the background on the four study countries with focus on policy issues on agricultural extension and subsidies, followed by a brief overview of the history of conservation agriculture and ending with an outline of the possible drivers of MTM adoption and diffusion in each country. The introductory section is followed by a section that offers a detailed description of the sampling and data-collection methods, the variables and the analytical approach frameworks. The 'Methods' section is followed by a presentation of the results from a probit estimation using the pooled and individual country samples as well as those from the post-estimation simulations. The final section concludes this paper by summarizing the key findings and stating the policy implications and suggestions for future research.

\section{Background of study countries: extension and subsidies}

In the eastern and southern Africa (ESA) region, agricultural extension services were somewhat neglected in the years after the 1980s, largely as a consequence of structural adjustment programmes (Rivera and Alex 2004; Pye-Smith 2012). In years since that period, there is now some renewed policy focus on agricultural extension. In 2010 for example, Ethiopia was estimated to be on track to have one of the most favourable ratios of extension-personnel-to-farmer ratios in Africa (projected to rise to 21 per 10,000 in short order (Davis et al. 2010)). This compares favourably with the recommendation in Pye-Smith (2012): a ratio of 33 extension agents for every 10,000 farmers was reported as the minimum ratio needed for an effective extension system. In Kenya, smallholder farmers have traditionally benefited from the government extension system supplemented by commodity-based programmes run by parastatal and private agribusiness corporations and farmer cooperatives. However, government budget allocation for extension services declined from $6 \%$ of the annual government budget in the 1980s to only $2 \%$ (in real terms) in the years since then (Muyanga and Jayne 2006). A new extension policy is now being implemented (Government of Kenya, 2012), reflecting a refocus on extension. In Tanzania, like the rest of the study countries, agricultural extension services are provided by the public sector through the Ministry of Agriculture. Recently, the National Agriculture Policy of 2007 stated the government's intention to increase the number of extension workers by about 15,000 (Daniel 2013). The government extension services also remain the major provider of extension services in Malawi (Masangano and Mthinda 2012). In 2000, a white paper with a bottom-up and participatory focus for planning was published to guide the extension system in the country (Masangano and Mthinda 2012).

In recent years, there has been a return of fertilizer subsidies in sub-Saharan Africa (SSA) after a period of their absence in the wake of the structural adjustment programmes of the 1980s and 1990s. For example, Malawi spent about $72 \%$ of its agricultural budget in 2008/2009 on agricultural input subsidies (Dorward and Chirwa 2010). The subsidized distribution of fertilizer and improved seeds (maize and beans) at $90 \%$ subsidy has played a big role in the wider use of these inputs in the country. In 2003, the government of Tanzania reinstated the fertilizer transport subsidy, and this was still operational in 2007 and in 2008 through the National Agricultural Input Voucher Scheme (NAIVs) (Pan and Christiaensen 2011). Although Kenya has a long 
history of relying on the private sector as a key driver in the fertilizer and seed markets, in 2013, the Kenyan Government introduced a fertilizer subsidy programme administered by the state cereal marketing board. In Ethiopia, the agricultural input sectors are mainly controlled by the state. Since 1994, aiming to reach many poor farmers who do not have cash to pay for inputs (fertilizer and seed), the government has been providing credit guarantees to help lower trade-financing costs and the national extension programme is often the major buyer and distributor of seeds and fertilizer in order to boost supplies of these (Kherallah et al. 2002).

\section{Background of conservation agriculture}

The history of conservation agriculture in the four countries suggests that its promotion is variously attributable to agricultural development projects (Milder et al. 2011). The emergence of conservation agriculture as a component of sustainable agriculture in ESA can be traced in the literature to the 1990s. At the 1996 World Food Summit, the Soil Fertility Initiative was launched, followed by the Better Land Husbandry approach. In 1998, a conservation tillage workshop was held in Zimbabwe, and in 2000, the African Conservation Tillage network was formed (Bishop-Sambrook et al. 2004). One of the early efforts to introduce minimum tillage in Ethiopia was done by Sasakawa-Global (SG2000) in South Achefer district (Matsumoto et al. 2004). In Kenya, conservation agriculture has been formally promoted since 1998 under the Kenya Conservation Tillage Initiative (KCTI), and by 2005, KCTI had projects in five districts in the country. The 3rd World Congress on Conservation Agriculture was held in Kenya, and the government (represented by the vice-president of Kenya at that time) expressed its commitment to conservation agriculture in its strategy to revitalize agriculture (ACT 2008 p. 9).

Interest in and research on conservation agriculture in Malawi date back to the 1980s at Bunda College (Mloza-Banda 2002). This interest has been sustained over the years, as evidenced by wide-ranging literature such as Munthali et al. (2008) on socioeconomic factors that affect adoption of conservation practices, Ngwira et al. (2013) on the estimated benefits of conservation agriculture for smallholders in terms of economic and biophysical outcomes, Ngwira et al. (2012) on the evaluation of conservation agriculture-based maize-legume intercropping systems and Kaczan et al. (2013) which provides a review of conservation agriculture in Malawi. In Tanzania, Marietha et al. (2011) report on a joint programme in 2004 run by the German Ministry of Agriculture and FAO-supported conservation agriculture practices in Northern Tanzania-one of the earliest concerted efforts to promote conservation agriculture in Tanzania. The project used farmer field schools as entry points for extension and farmer education on conservation agriculture, and the private sector was encouraged to participate by retailing and developing custom hire services for conservation agriculture equipment.

\section{Possible drivers of MTM adoption and diffusion}

At the farm level, an oft-cited advantage of MTM is that it lowers the costs involved in land preparation (Fowler and Rockstrom 2001). For example, reduced tractor and fuel 
costs have been a major driver of adoption in mechanized large-scale systems, especially if herbicides are available to manage increased weed pressure (Erenstein et al. 2012). There is mixed evidence regarding yield increases due to reduced or minimum tillage (Giller et al. 2009). The evidence on mulching is also mixed, being complicated by the critical trade-offs between mulch, feed and other uses (Jaleta et al. 2013, 2015). In Morocco, Magnan et al. (2012) calculated the opportunity costs of crop residue in no-till systems and found that the shadow value (its value in livestock feeding as opposed to soil mulch) was $25 \%$ of the total value of the crop produced during normal rainfall and 75\% during drought (when crop residues become most valuable as animal feed). Similarly, a study by Valbuena et al. (2012) comparing conservation agriculture practices in South Asia and sub-Saharan Africa showed that the use of crop residues for mulching was most feasible in 'high-potential areas' where biomass production levels are likely to be high enough to meet the demands of both livestock and mulching.

The implementation of conservation agriculture can represent significant learning costs for farmers who can ill afford extended periods of trial and perhaps error. For resource poor farmers, the financial resources needed for complementary external inputs such as herbicides or fertilizers to implement MTM properly, and the increased labour needed for weed management, can still represent serious challenges if their main resource is family labour. In situations where opportunities for accessing credit or earning cash incomes are limited, and where MTM requires significant commitment of learning time, cash or labour, adoption may prove sluggish (Jack 2013).

\section{Methods}

\section{Data and data sources}

This study focuses on maize-legume-based production systems, the prevailing system across the four countries. The study regions were selected to generally coincide with the dominant smallholder maize production areas identified as important for smallholder productivity growth and poverty reduction by the national agricultural development authorities. The study areas were part of a multidisciplinary project designed to test various options for encouraging the diffusion of conservation agriculture-based practices in the smallholder farming systems of eastern and southern Africa. The project focused on (among other things) generating information on maize-legume value chains and policies and to inform farmers, extension agencies, non-governmental organizations and agribusinesses along the maize-legume value chain about opportunities for the adoption of conservation agriculture based practices leading to sustainable agricultural intensification.

In Ethiopia, the survey was carried out in the maize-legume-based farming systems in three regions of the country: SNNP, ${ }^{4}$ Benshangul and Oromia regions. Multi-stage sampling was employed to select households to be included in the survey. In the first stage, 39 districts were purposively selected based on the importance of maize. In the second stage, 69 Peasant Associations (PAs) were randomly picked from a list of PAs in each district. In the final stage, a total of 2187 households were randomly selected from the various PAs, with the number of households selected from each PA proportional to 
the number of the households in the PA as per the latest official national population census figures.

In Kenya, two districts were selected from western Kenya (Bungoma and Siaya) and three districts from eastern Kenya (Embu, Meru South and Imenti South). Multi-stage sampling was employed to select lower-level sampling clusters: divisions, locations, sub-locations and villages. In total, 30 divisions were selected-17 from western Kenya and 13 from eastern Kenya. In total, 613 households were included in the Kenya survey with the two regions being assigned approximately 300 households each. Efforts were made to ensure representativeness of the sample depending on the population of the sampling units. Proportionate random sampling was designed to select divisions from each district, sub-locations from each division, villages from each sub-location and number of households from each village. Therefore, the households in a region were distributed across the districts according to the census of farm households per district.

In Malawi, purposive sampling was also used in the first stage to select regions of the country where smallholder maize-farming was important. Stratified sampling was used to select six districts, five in the central region (Lilongwe, Kasungu, Mchinji, Salima and Ntcheu) and one (Balaka) in the south. Eventually, 64 Extension Planning Areas (EPA's), 89 sections and 235 villages were selected using multi-stage random sampling combined with probability to proportional size. Using the same process, 1870 households from the 235 villages were selected for this study.

In Tanzania, the survey targeted two maize-legume-based farming systems: Kilosa and Mvomero in the eastern zone and Mbulu and Karatu districts in the northern zone. These districts were purposively selected, followed by multi-stage random sampling to arrive at a total sample of 60 villages, and using probability proportional to size, a final sample tally of 681 households was considered in the survey. From the four countries, the total data set comprised 5356 farm households and 11,188 maize plots from 700 villages in 43 districts. Figure 1 shows the location of the study districts across the four countries.

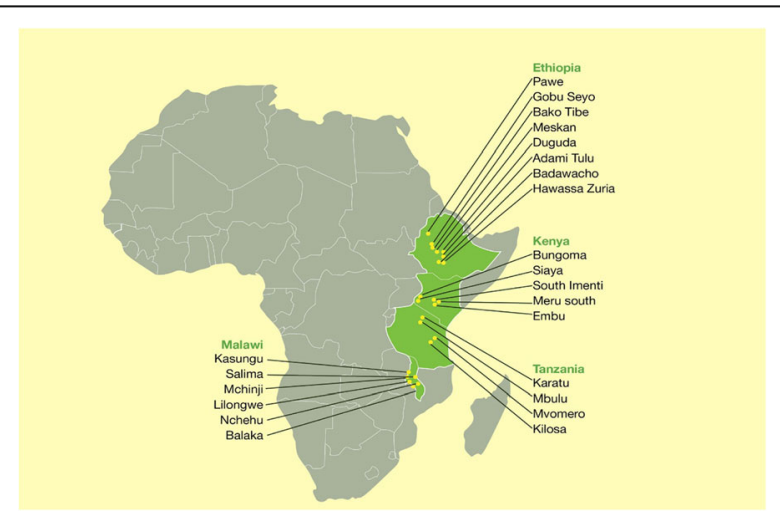

Fig. 1 Key study locations in Ethiopia, Kenya, Malawi and Tanzania (due to space limitations, not all the 39 districts in Ethiopia are displayed. The figure represents the range of agro-ecologies covered in the Ethiopia sample) 


\section{Variables included in the adoption model}

When deciding whether or not to implement MTM, the initial decision can be construed as making a binary choice. The subsequent decisions such as the area on which MTM is implemented would be seen as continuous. Several elements in this process condition the final choice: the environment in which farmers operate; observed household and farm characteristics (e.g. gender, educational attainment, age, plot characteristics); unobserved attributes (risk attitudes, motivation, etc.), among others (Kassie et al. 2015; Marenya and Barrett 2007). We used a set of farm-household and environment indicators in a probit model to estimate the factors that affect plot-level adoption in the study sites. We describe below the groups of variables and the hypotheses informing their use in the adoption model. The variables range from self-reported assessments of plot-level characteristics to household demographics such as education level of the household head and main income activities. Finally, we explain the two policy variables included in the adoption model and used in the simulation framework.

\section{Plot characteristics}

Plot-related variables play a significant role in predicting adoption. For example, Kaizzi et al. (2002) and Yanggen et al. (1998) found a tendency for farmers to apply organic soil-fertility management practices on plots with poor soil fertility and fertilizer on plots with high fertility. We include self-reported plot characteristics in the adoption model (such as the farmer's view of the slope of the plot: whether steep, gentle or flat, and his perceptions on the fertility level: whether poor, average or good) to control for these effects in MTM adoption.

\section{Physical capital and livestock ownership}

Physical capital endowment should generally be a positive predictor of adoption of diverse types of practices. These variables can proxy for access to equipment and liquidity and serve as a buffer stock against shocks in the absence of affordable and accessible formal insurance and credit markets. Livestock endowment has been frequently reported as having a significant positive impact on adoption of fertilizer and manure, although greater livestock ownership can have a negative impact on the adoption of MTM due to competition for crop residues between mulch and feed. Ryan and Spencer (2001) showed that farmers with mixed livestock-crop systems are able to enhance soil fertility more sustainably than those growing crops or keeping livestock only. Farm size can be expected to be positively associated with greater technology adoption, as this is a proxy for higher resource endowments not captured by livestock or value of farm equipment.

\section{Household demographics and human capital}

Sex, education or farming experience, and age of the decision-maker or household head, can be predictors of technology adoption. For example, in many rural societies, there are marked differences between men and women farmers: women in sub-Saharan Africa have a disproportionately lower share and control of agricultural resources (land, fertilizer, labour, information and finance) than men, incommensurate with their level of contribution to agricultural labour (e.g. Peterman et al. 2011; Slavchevska 2015). Hence, women farmers may use technologies that save 
on their scarce resources (e.g. use manure instead of more expensive fertilizer). Male-headed households mostly consist of husband and wife and thus are likely to have more adult members for implementing labour-demanding practices. Family labour is one of the most important sources of farm power when households lack cash to hire equipment or use labour markets to bring in extra labour. Bettereducated farmers are more likely to use knowledge-intensive practices due to greater access to extension or ability to acquire, process and use information and experiment with new practices. Ability to earn extra income from off-farm employment means that a household has access to cash for inputs and hiring labour to implement agricultural practices such as MTM.

\section{Access to markets and rural services}

Proximity to markets reduces the cost of acquiring inputs and selling outputs, thus increasing the profitability of technology adoption. Farmers closer to agricultural markets are more likely to use modern inputs since transaction costs (lower transportation and information-gathering costs) are lower. Access to credit helps farmers to access the finance needed at critical times for purchase of inputs, hiring labour and consumption-smoothing, thus making the adoption of resourceintensive practices easier.

\section{Policy variables}

Greater investment in agricultural extension to increase the availability of information and subsidies designed to relieve financial and credit constraints to adoption are two policy strategies that can be used to encourage widespread adoption and upscaling of MTM and associated practices. The consensus in much of the literature is that carefully designed subsidies that lower the overall cost of inputs can enable liquidityconstrained farmers to overcome short-term financing constraints, and make it easier for them to use herbicides, fertilizer and hire equipment to implement MTM. The key design principles of a sustainable subsidy policy that could help in achieving these objectives will depend on careful targeting and reliance on existing input-market channels as much as possible (Smale et al. 2011).

In terms of information availability and farmer-capacity enhancement, agricultural extension is a critical public service. Farmers may fail to adopt a technology if they lack the information on how best to implement recommended practices (Jack 2013). Policywise, there is a new impetus to revamping extension services in many parts of ESA after some years of neglect subsequent to the 1980s contraction of public expenditures in many countries in ESA (Rivera and Alex 2004; Pye-Smith 2012). At the peak of investment in extension in the pre-structural adjustment years, the developing country average of extension-agent-to-farmer ratio was 1 to 300, a number that had declined to 1 to $1500-3000$ by 2012 (Pye-Smith 2012). The importance of extension for MTM adoption was highlighted by Milder et al. (2011):

"...the single most effective way to scale up CA for smallholder farmers is to vastly increase extension support and technical backstopping. Since the successful adoption of CA requires a departure from conventional farming methods-supported by a new knowledge base-there is really no substitute for a dense network of trainers 
and extension at the field level. This is particularly true for the many parts of Africa where existing levels of capacity are very low..."

\section{Policy simulations}

To capture the relative importance of these two policy issues, we implemented a series of policy simulations based on the probit regression model results. The expected predicted probabilities of adoption under different extension and subsidy-expenditure scenarios were compared. Specifically, we simulate the following three types of scenarios:

\section{(a) Base model:}

In the base scenario, the expected probability ${ }^{5}$ of MTM adoption in country $i$ is denoted as $\mathrm{E}\left[\operatorname{Pr}\left(\mathrm{MTM}_{i} \mid \mathrm{p}_{i}\right)\right]$. The base scenario is derived by setting the relevant policy variables (extension-to-farmer ratio or proportion of expenditure on subsidies) at respective country $i$ 's observed value, where $i=$ Ethiopia, Kenya, Malawi and Tanzania.

(b) Changing the policy variables from the base levels:

In these scenarios, the expected probability of MTM adoption $\mathrm{E}\left[\operatorname{Pr}\left(\mathrm{MTM}_{\mathrm{i}} \mid p_{j}\right)\right]$, in country $i$ is computed by letting the policy variable take on an alternative value $p_{j}$ (where $i \neq j$ ) and $j=$ Ethiopia, Kenya, Malawi and Tanzania. In this case, $j$ would be the policy value from the country which best typifies the policy in question. For expenditure on input subsidies, Malawi had the highest expenditure (see Table 1), so in this simulation scenario, the other three countries' expenditure on input subsidies was changed to Malawi's level. For extension-to-farmer ratios (EFRs), Ethiopia had the highest (Table 1), so the EFRs of the other three countries were changed to Ethiopia's level.

(c) Combining different levels of the two policies:

In a third category of comparisons, we combine different levels of subsidy expenditure and EFRs to reflect the fact that policies can be combined. This is denoted as $\mathrm{E}\left[\operatorname{Pr}\left(\mathrm{MTM}_{i} \mid p_{i}, p_{j},\right)\right]$, the expected probability of CA adoption in country $i$ when the policy variable takes on a different combination of EFR or subsidyexpenditure levels. In this case, $p_{i}$ and $p_{j}$ would be a set of two policies specifically based on varying a policy variable and another aspect of interest (e.g. availability of credit). The choice of the country value combinations was based on which value pair best typified the policy combination of interest. More details are presented in the simulation results section.

Table 1 Policy simulation variables

\begin{tabular}{|c|c|c|c|c|c|}
\hline & Ethiopia & Kenya & Malawi & Tanzania & Average \\
\hline \multicolumn{6}{|c|}{ Extension personnel per 10,000 farmers (EFR) } \\
\hline & 16.0 & 10.0 & 6.2 & 4.0 & 9.0 \\
\hline Period & 2010 & 2012 & 2008 & 2010 & 2008-2012 \\
\hline Source & Davis et al. (2010) & $\begin{array}{l}\text { Government of Kenya } \\
\text { (2012) }\end{array}$ & Pablo et al. (2008) & Davis et al. (2010) & \\
\hline \multicolumn{6}{|c|}{ Input subsidy expenditure as a percent of public agriculture spending (\%) (SER) } \\
\hline & 10.4 & 19.0 & 58.9 & 46.0 & 33.6 \\
\hline Period & 2009-2011 & 2009-2011 & 2009-2011 & 2009-2011 & 2009-2012 \\
\hline Source & $\begin{array}{l}\text { Jayne and Rashid } \\
\text { (2013) }\end{array}$ & $\begin{array}{l}\text { Jayne and Rashid } \\
\text { (2013) }\end{array}$ & $\begin{array}{l}\text { Jayne and Rashid } \\
\text { (2013) }\end{array}$ & $\begin{array}{l}\text { Jayne and Rashid } \\
\text { (2013) }\end{array}$ & \\
\hline
\end{tabular}


Table 1 shows the EFR and subsidy expenditure as a percentage of agricultural budgets (SER) in each of the four countries. We chose data for the year 2010 because the household data were also collected during 2010. In cases where the data for EFR and SER for 2010 were not available, we chose the data for the year nearest to 2010. In terms of EFR-measured as the number of frontline extension staff per 10,000 farmers-Ethiopia had the highest EFR at 16, followed by Kenya (10), Malawi (6) and Tanzania (4). Malawi spent the most on input subsidies (58.9\% of the whole agricultural ministry budget) between 2009 and 2011, compared to Ethiopia (10\%), Kenya (19\%) and Tanzania (46\%) of total agricultural ministry budgets.

\section{Results and discussion}

\section{Household variables descriptive statistics}

We summarize the descriptive statistics in Table 2. These data show that MTM was variously used in the study sites of Ethiopia (30\% of all plots observed), $4 \%$ of the plots in Kenya, 35\% in Malawi and 11\% in Tanzania had MTM and overall 22\% of the plots across the four countries (Fig. 1). These percentages are consistent with what has been published in recent literature. For example, Kassie et al. (2014) showed a 30\% adoption of minimum tillage in Ethiopia. In Kenya, maize-legume rotations and no- or minimum-tillage adoption were reported to be 4 and $4.5 \%$, respectively, by Ndiritu et al. (2014). Ngwira et al. (2014) reported the results of a survey of six districts in the central and southern regions of Malawi and found adoption rates of CA ranging between 1.5 and 38.9\%. In Tanzania, Kahimba et al. (2014) reported that in the Arusha region, 23.7\% of farmers were adopting minimum tillage practices (such as zero tillage, ripping and minimum tillage) and in the Dodoma region $29.1 \%$ had adopted planting pits (chololo).

Regarding the demographics of the farming population, this sample shows that on average, a Kenyan farmer was older (50 years) compared to an average Tanzanian (45 years), Ethiopian (43 years) and Malawian (42 years) farmer. The Kenyan farmer had on average 7.5 years of formal schooling compared to 3.0 in Ethiopia, 5.7 in Malawi and 5.4 in Tanzania. Only a minority of households had any non-farm sources of income: $23 \%$ in Kenya, 13\% in Malawi, 6\% in Tanzania and 5\% in Ethiopia. The average household size ranged from five members in Malawi to seven in Ethiopia. As expected, households in Ethiopia had the highest livestock numbers (6.24 TLUs or tropical livestock units) and Malawi had the lowest (0.72 TLUs). Farm size cultivated during the major agricultural season was the smallest in Kenya (1.32 ha) and the highest in Tanzania (4.7 ha) followed by Malawi (3.4 ha) and Ethiopia (2.6 ha). The value of non-livestock assets was highest in Ethiopia (\$883) and lowest in Tanzania (\$152). The credit-constraint data show that, typically, about $50 \%$ of households reported needing credit and not finding it. In Ethiopia, Kenya and Malawi, 56, 45 and 49\% of households, respectively, were credit constrained. In Tanzania, relatively few households reported needing credit and not finding it. Overall, $25 \%$ of the farmers belonged to various types of farmers' groups: approximately $20 \%$ in Ethiopia, 20\% in Kenya, 39\% in Malawi and about 25\% in Tanzania.

\section{Results from adoption model}

Table 3 presents the results from the adoption model. We discuss each group of variables in turn. 
Table 2 Variable definitions and summary statistics

\begin{tabular}{|c|c|c|c|c|c|c|c|c|c|c|}
\hline \multirow[t]{2}{*}{ Variable Description } & \multicolumn{2}{|c|}{$\begin{array}{l}\text { Pooled } \\
(N=11,188)\end{array}$} & \multicolumn{2}{|c|}{$\begin{array}{l}\text { Ethiopia } \\
(N=3861)\end{array}$} & \multicolumn{2}{|c|}{$\begin{array}{l}\text { Kenya } \\
(N=2851)\end{array}$} & \multicolumn{2}{|c|}{$\begin{array}{l}\text { Malawi } \\
(N=2937)\end{array}$} & \multicolumn{2}{|c|}{$\begin{array}{l}\text { Tanzania } \\
(N=1539)\end{array}$} \\
\hline & Mean & SD & Mean & SD & Mean & SD & Mean & SD & Mean & SD \\
\hline Minimum tillage and mulching & 0.22 & 0.41 & 0.30 & 0.46 & 0.05 & 0.21 & 0.35 & 0.48 & 0.11 & 0.31 \\
\hline $\begin{array}{l}\text { Sex of household head } \\
\text { (male }=1 \text {, female }=0)\end{array}$ & 0.87 & 0.33 & 0.94 & 0.24 & 0.82 & 0.39 & 0.83 & 0.37 & 0.88 & 0.32 \\
\hline Age of the household head (years) & 45.0 & 14.2 & 42.5 & 12.7 & 50.7 & 14.3 & 42.4 & 14.4 & 45.9 & 13.8 \\
\hline $\begin{array}{l}\text { Education of the household head } \\
\text { (years of schooling completed) }\end{array}$ & 5.21 & 3.96 & 3.03 & 3.33 & 7.54 & 3.82 & 5.73 & 3.74 & 5.40 & 3.16 \\
\hline \multicolumn{11}{|l|}{ Main source of income: } \\
\hline Crop and livestock farming & 0.93 & 0.26 & 0.99 & 0.11 & 0.77 & 0.42 & 1.0 & NA & 0.94 & 0.23 \\
\hline Salaried employment & 0.03 & 0.16 & 0.01 & 0.08 & 0.08 & 0.27 & NA & NA & 0.04 & 0.19 \\
\hline Non-farm self-employment & 0.03 & 0.17 & 0.00 & 0.05 & 0.10 & 0.30 & NA & NA & 0.02 & 0.13 \\
\hline Casual labour & 0.02 & 0.13 & 0.00 & 0.05 & 0.06 & 0.23 & NA & NA & 0.002 & 0.04 \\
\hline Number of family members & 5.98 & 2.56 & 6.81 & 2.60 & 5.85 & 2.70 & 5.21 & 2.17 & 5.65 & 2.29 \\
\hline $\begin{array}{l}\text { Livestock owned (in tropical } \\
\text { livestock units (TLU)) }\end{array}$ & 4.75 & 6.19 & 6.24 & 5.74 & 2.40 & 2.47 & 0.72 & 1.74 & 3.49 & 7.15 \\
\hline Total farm size cultivated (ha) & 2.75 & 3.12 & 2.58 & 1.85 & 1.32 & 3.14 & 3.38 & 2.60 & 4.66 & 4.78 \\
\hline $\begin{array}{l}\text { Total non-livestock assets owned } \\
\text { by the household in (\$) }\end{array}$ & 647 & 1163 & 883 & 1371 & 740 & 1134 & 506 & 1033 & 152 & 507 \\
\hline $\begin{array}{l}\text { Household is credit constrained } \\
\text { (yes }=1 \text { ) }\end{array}$ & 0.47 & 0.50 & 0.56 & 0.50 & 0.45 & 0.50 & 0.49 & 0.50 & 0.26 & 0.44 \\
\hline $\begin{array}{l}\text { Respondent confident in skill and } \\
\text { advice of extension provider } \\
\text { (yes=1) }\end{array}$ & 0.28 & 0.45 & 0.29 & 0.45 & 0.26 & 0.44 & 0.25 & 0.43 & 0.39 & 0.49 \\
\hline Perceived plot soil fertility & & & & & & & & & & 0.52 \\
\hline Poor & 0.11 & 0.31 & 0.07 & 0.25 & 0.14 & 0.35 & 0.14 & 0.34 & 0.08 & 0.28 \\
\hline Medium & 0.50 & 0.50 & 0.47 & 0.50 & 0.54 & 0.50 & 0.39 & 0.49 & 0.72 & 0.45 \\
\hline Good & 0.39 & 0.49 & 0.47 & 0.50 & 0.32 & 0.47 & 0.48 & 0.50 & 0.20 & 0.40 \\
\hline \multicolumn{11}{|l|}{ Perceived plot slopes } \\
\hline Gentle/flat & 0.57 & 0.50 & 0.67 & 0.47 & 0.47 & 0.50 & 0.62 & 0.49 & 0.39 & 0.49 \\
\hline Medium & 0.37 & 0.48 & 0.30 & 0.46 & 0.49 & 0.50 & 0.27 & 0.44 & 0.51 & 0.50 \\
\hline Steep & 0.06 & 0.24 & 0.03 & 0.17 & 0.04 & 0.20 & 0.11 & 0.31 & 0.10 & 0.29 \\
\hline $\begin{array}{l}\text { Number of grain traders from } \\
\text { outside village known to } \\
\text { respondent }\end{array}$ & 4.26 & 6.20 & 4.21 & 5.35 & 3.52 & 3.59 & 6.14 & 6.04 & 2.19 & 10.10 \\
\hline $\begin{array}{l}\text { Number of non-relatives from } \\
\text { outside the village respondent } \\
\text { can rely on for help }\end{array}$ & 4.27 & 8.30 & 4.93 & 10.84 & 5.98 & 8.80 & 2.66 & 4.00 & 2.54 & 4.23 \\
\hline $\begin{array}{l}\text { Household head belongs to a } \\
\text { farmers' association (cooperatives, } \\
\text { etc.) } 1=\text { yes, } 0 \text { otherwise }\end{array}$ & 0.25 & 0.44 & 0.20 & 0.40 & 0.19 & 0.40 & 0.39 & 0.49 & 0.25 & 0.43 \\
\hline $\begin{array}{l}\text { Walking minutes to the nearest } \\
\text { market }\end{array}$ & 64.79 & 61.42 & 47.99 & 34.67 & 80.65 & 54.72 & 32.69 & 26.47 & 138.83 & 94.36 \\
\hline $\begin{array}{l}\text { Drought perceived as a major } \\
\text { future risk (yes }=1 \text { ) }\end{array}$ & NA & NA & NA & NA & 0.15 & 0.36 & NA & NA & NA & NA \\
\hline $\begin{array}{l}\text { Pests and diseases perceived } \\
\text { as a major future risk (yes }=1 \text { ) }\end{array}$ & NA & NA & NA & NA & 0.15 & 0.36 & NA & NA & NA & NA \\
\hline $\begin{array}{l}\text { High input and low crop prices } \\
\text { perceived as a major future } \\
\text { risk (yes }=1 \text { ) }\end{array}$ & NA & NA & NA & NA & 0.19 & 0.39 & NA & NA & NA & NA \\
\hline $\begin{array}{l}\text { Personal health or economic situation } \\
\text { perceived as a major future risk (yes }=1 \text { ) }\end{array}$ & NA & NA & NA & NA & 0.17 & 0.38 & NA & NA & NA & NA \\
\hline
\end{tabular}


Table 3 Probit estimation of factors that affect plot level adoption of minimum tillage in Ethiopia, Kenya, Malawi and Tanzania

\begin{tabular}{|c|c|c|c|c|c|c|}
\hline VARIABLES & $\begin{array}{l}\text { Pooled with } \\
\text { country dummies }\end{array}$ & $\begin{array}{l}\text { Pooled with country } \\
\text { EFR }^{\mathrm{a}} \text { and SER } \\
\text { variables }\end{array}$ & Ethiopia & Kenya & Malawi & Tanzania \\
\hline \multirow{2}{*}{$\begin{array}{l}\text { Sex of household head } \\
(\text { male }=1, \text { female }=0)\end{array}$} & $0.082^{*}$ & $0.082^{*}$ & -0.021 & $0.417^{* * *}$ & 0.067 & 0.102 \\
\hline & $(0.047)$ & $(0.047)$ & $(0.103)$ & $(0.151)$ & $(0.069)$ & $(0.152)$ \\
\hline \multirow{2}{*}{$\begin{array}{l}\text { Age of the household } \\
\text { head (years) }\end{array}$} & -0.001 & -0.001 & -0.000 & -0.000 & -0.001 & 0.004 \\
\hline & $(0.001)$ & $(0.001)$ & $(0.002)$ & $(0.004)$ & $(0.002)$ & $(0.004)$ \\
\hline \multirow{2}{*}{$\begin{array}{l}\text { Education of the } \\
\text { household head (years } \\
\text { completed) }\end{array}$} & 0.002 & 0.002 & 0.002 & $-0.031^{* *}$ & 0.007 & 0.020 \\
\hline & $(0.004)$ & $(0.004)$ & $(0.007)$ & $(0.014)$ & $(0.007)$ & $(0.017)$ \\
\hline \multicolumn{7}{|l|}{ Main source of income is } \\
\hline \multirow{2}{*}{$\begin{array}{l}\text { Salaried employment } \\
\text { (c.f. farming) }\end{array}$} & -0.158 & -0.158 & $-0.913^{* *}$ & -0.092 & \multirow{6}{*}{$\begin{array}{l}\text { Not } \\
\text { estimated }\end{array}$} & -0.181 \\
\hline & $(0.128)$ & $(0.128)$ & $(0.394)$ & $(0.196)$ & & $(0.257)$ \\
\hline \multirow{2}{*}{$\begin{array}{l}\text { Non-farm self- } \\
\text { employment } \\
\text { (c.f. farming) }\end{array}$} & 0.028 & 0.028 & 0.015 & $-0.456^{* *}$ & & $-0.533^{*}$ \\
\hline & $(0.126)$ & $(0.126)$ & $(0.516)$ & $(0.206)$ & & $(0.289)$ \\
\hline \multirow{2}{*}{$\begin{array}{l}\text { Casual labour } \\
\text { (c.f. farming) }\end{array}$} & $0.247^{*}$ & $0.247^{*}$ & 0.55 & 0.247 & & \multirow{2}{*}{$\begin{array}{l}\text { Not } \\
\text { estimated }\end{array}$} \\
\hline & $(0.149)$ & $(0.149)$ & $(0.405)$ & $(0.183)$ & & \\
\hline \multirow{2}{*}{$\begin{array}{l}\text { Number of family } \\
\text { members }\end{array}$} & $-0.010^{*}$ & $-0.010^{*}$ & $-0.017^{*}$ & -0.006 & 0.000 & 0.000 \\
\hline & $(0.006)$ & $(0.006)$ & $(0.010)$ & $(0.021)$ & $(0.012)$ & $(0.022)$ \\
\hline \multirow{2}{*}{$\begin{array}{l}\text { Livestock owned (in } \\
\text { tropical livestock } \\
\text { equivalent }(T L U) \text { ) }\end{array}$} & -0.000 & -0.000 & $-0.010^{* *}$ & -0.052 & -0.000 & 0.005 \\
\hline & $(0.000)$ & $(0.000)$ & $(0.005)$ & $(0.032)$ & $(0.000)$ & $(0.007)$ \\
\hline \multirow{2}{*}{$\begin{array}{l}\text { Total farm size in } \\
\text { long rain season (ha) }\end{array}$} & $0.008^{*}$ & $0.008^{*}$ & $0.112^{* * *}$ & $-0.107^{*}$ & 0.003 & $-0.065^{* * *}$ \\
\hline & $(0.005)$ & $(0.005)$ & $(0.014)$ & (0.059) & $(0.008)$ & $(0.020)$ \\
\hline \multirow{2}{*}{$\begin{array}{l}\text { Total non-livestock } \\
\text { assets owned by the } \\
\text { household in '000s } \\
\text { US\$ }\end{array}$} & $0.023^{*}$ & $0.023^{*}$ & $-0.035^{*}$ & $-0.162^{* *}$ & $0.089 * * *$ & $0.023^{*}$ \\
\hline & $(0.0012)$ & $(0.012)$ & $(0.018)$ & $(0.066)$ & $(0.025)$ & $(0.012)$ \\
\hline \multirow{2}{*}{$\begin{array}{l}\text { Number of grain } \\
\text { traders from outside } \\
\text { village known to } \\
\text { respondent }\end{array}$} & $-0.004^{* *}$ & $-0.004^{* *}$ & $-0.007^{*}$ & 0.008 & -0.000 & $-0.059^{* * *}$ \\
\hline & $(0.002)$ & $(0.002)$ & $(0.004)$ & $(0.008)$ & $(0.003)$ & $(0.015)$ \\
\hline \multirow{2}{*}{$\begin{array}{l}\text { Number of non- } \\
\text { relatives outside } \\
\text { village respondent } \\
\text { can rely on for help }\end{array}$} & $0.005^{* * *}$ & $0.005^{* * *}$ & $0.007^{* * *}$ & $-0.011^{*}$ & 0.005 & $0.019^{* * *}$ \\
\hline & $(0.001)$ & $(0.001)$ & $(0.001)$ & $(0.006)$ & $(0.003)$ & $(0.007)$ \\
\hline \multirow{2}{*}{$\begin{array}{l}\text { Household head } \\
\text { belongs to a } \\
\text { farmers' association } \\
\text { (cooperatives etc.) } \\
1=\text { yes, } 0 \text { otherwise }\end{array}$} & $0.107^{* * *}$ & $0.107^{* * *}$ & $0.613^{* * *}$ & 0.129 & $-0.242^{* * *}$ & 0.166 \\
\hline & $(0.033)$ & $(0.033)$ & $(0.055)$ & $(0.123)$ & $(0.052)$ & $(0.113)$ \\
\hline \multirow{2}{*}{$\begin{array}{l}\text { Household is credit } \\
\text { constrained (yes }=1 \text { ) }\end{array}$} & $-0.218^{* * *}$ & $-0.218^{* * *}$ & $-0.267^{* * *}$ & $-0.219^{* *}$ & -0.062 & $-0.759^{* * *}$ \\
\hline & $(0.029)$ & $(0.029)$ & $(0.046)$ & $(0.096)$ & $(0.049)$ & $(0.144)$ \\
\hline \multirow{2}{*}{$\begin{array}{l}\text { Respondent confident } \\
\text { in skill and advice of } \\
\text { extension provider } \\
(\text { yes }=1 \text { ) }\end{array}$} & $0.064^{* *}$ & $0.064^{* *}$ & $0.097^{*}$ & $0.382^{* * *}$ & 0.044 & 0.145 \\
\hline & $(0.035)$ & $(0.031)$ & $(0.050)$ & $(0.100)$ & $(0.056)$ & $(0.108)$ \\
\hline \multirow{2}{*}{$\begin{array}{l}\text { Medium soil fertility } \\
\text { (c.f. poor soil fertility) }\end{array}$} & 0.082 & 0.082 & $0.207^{* *}$ & $0.437^{* *}$ & 0.042 & $0.548^{* * *}$ \\
\hline & $(0.051)$ & $(0.051)$ & (0.099) & $(0.179)$ & $(0.076)$ & $(0.204)$ \\
\hline \multirow{3}{*}{$\begin{array}{l}\text { Good soil fertility } \\
\text { (c.f. poor soil fertility) }\end{array}$} & -0.038 & -0.038 & $0.304^{* * *}$ & $0.553^{* * *}$ & $-0.337^{* * *}$ & $0.524^{* *}$ \\
\hline & $(0.051)$ & $(0.051)$ & $(0.100)$ & $(0.187)$ & $(0.075)$ & $(0.218)$ \\
\hline & $0.180^{* * *}$ & $0.180^{* * *}$ & $0.343^{* * *}$ & $0.231^{* *}$ & 0.029 & $0.234^{* *}$ \\
\hline
\end{tabular}


Table 3 Probit estimation of factors that affect plot level adoption of minimum tillage in Ethiopia, Kenya, Malawi and Tanzania (Continued)

\begin{tabular}{|c|c|c|c|c|c|c|}
\hline $\begin{array}{l}\text { Medium sloped plot } \\
\text { (c.f. gentle/flat) }\end{array}$ & $(0.032)$ & $(0.032)$ & $(0.050)$ & $(0.100)$ & $(0.056)$ & $(0.103)$ \\
\hline $\begin{array}{l}\text { Steep sloped plot } \\
\text { (c.f. gentle/flat) }\end{array}$ & $-0.199^{* * *}$ & $-0.199^{* * *}$ & -0.089 & 0.228 & $-0.136^{*}$ & $-0.854^{* * *}$ \\
\hline \multirow{2}{*}{$\begin{array}{l}\text { Walking minutes to } \\
\text { the nearest market }\end{array}$} & $-0.001^{* * *}$ & $-0.001^{* * *}$ & 0.000 & 0.000 & $-0.002^{* *}$ & $-0.003^{* * *}$ \\
\hline & $(0.000)$ & $(0.000)$ & $(0.001)$ & $(0.001)$ & $(0.001)$ & $(0.001)$ \\
\hline \multirow[t]{2}{*}{ Kenya dummy } & $-1.168^{* * *}$ & & & & & \\
\hline & $(0.057)$ & & & & & \\
\hline \multirow[t]{2}{*}{ Malawi dummy } & $0.359^{* * *}$ & & & & & \\
\hline & $(0.076)$ & & & & & \\
\hline \multirow[t]{2}{*}{ Tanzania dummy } & $-0.669^{* * *}$ & & & & & \\
\hline & $(0.061)$ & & & & & \\
\hline \multirow{2}{*}{$\begin{array}{l}\text { Number of extension } \\
\text { personnel per 10,000 } \\
\text { farmers }\end{array}$} & & $0.151^{* * *}$ & & & & \\
\hline & & $(0.007)$ & & & & \\
\hline \multirow{2}{*}{$\begin{array}{l}\text { Percent of agricultural } \\
\text { budget spent on } \\
\text { subsidy }\end{array}$} & & $0.055^{* * *}$ & & & & \\
\hline & & $(0.004)$ & & & & \\
\hline \multirow{2}{*}{$\begin{array}{l}\text { Drought perceived as } \\
\text { a major future risk } \\
\text { (yes =1) }\end{array}$} & & & & $0.266^{* *}$ & & \\
\hline & & & & $(0.104)$ & & \\
\hline \multirow{2}{*}{$\begin{array}{l}\text { Pests and diseases } \\
\text { perceived as a major } \\
\text { future risk (yes }=1 \text { ) }\end{array}$} & & & & 0.019 & & \\
\hline & & & & $(0.104)$ & & \\
\hline \multirow{2}{*}{$\begin{array}{l}\text { High input and low } \\
\text { crop prices perceived } \\
\text { as a major future risk } \\
(\text { yes }=1)\end{array}$} & & & & -0.018 & & \\
\hline & & & & $(0.115)$ & & \\
\hline \multirow{2}{*}{$\begin{array}{l}\text { Personal health or } \\
\text { economic situation } \\
\text { perceived as a major } \\
\text { future risk (yes }=1 \text { ) }\end{array}$} & & & & $0.773^{* * *}$ & & \\
\hline & & & & $(0.103)$ & & \\
\hline \multirow[t]{2}{*}{ Constant } & -0.080 & $-3.941^{* * *}$ & $-0.352^{*}$ & $-1.231^{* * *}$ & -0.090 & $-0.891^{* *}$ \\
\hline & $(0.099)$ & $(0.353)$ & $(0.182)$ & $(0.384)$ & $(0.167)$ & $(0.401)$ \\
\hline
\end{tabular}

${ }^{a}$ Extension-personnel-to-farmer ratio

bSubsidy as a percentage of agricultural expenditures

${ }^{*}, * *$ and ${ }^{* * *}$ refer to the significance levels of $10 \%, 5 \%$ and $1 \%$ respectively

\section{Household demographics}

In this category, the sex of the household head was significant only in Kenya and in the pooled sample. Having more years of education was significantly and negatively associated with adoption of MTM in the Kenyan sample. Farmers who had paid employment were less likely to have adopted MTM (coefficient negative for all samples and significant for the Ethiopian sample). Similarly, those who had non-farm self-employment were less likely to have MTM on their plots (Kenyan sample) but more likely in the Tanzanian sample. The negative correlation with access to non-farm income may suggest higher opportunity costs for these households, thereby limiting the extent to which they will commit to working on their own farms and suggesting perhaps that MTM may impose non-trivial labour demands (hence, the high opportunity cost implied here) unless on-farm productivity gains and incomes can offset these apparently higher labour demands from MTM. 


\section{Access to infrastructure, markets and agricultural extension}

Those who reported that they were credit constrained were significantly less likely to have adopted MTM (except in Malawi where the coefficient was insignificant but still negative). This is indicative of the importance of credit and availability of finance in MTM adoption. The longer the distance to the nearest market, the less likely was MTM to have been adopted in any of the household's plots in Malawi and Tanzania, suggesting a strong effect of market access even when practices require inputs that may be available on-farm (e.g. mulch). Finally, those farmers who reported confidence in the skills and advice of their extension staff were more likely to have plots with MTM (in the pooled, Ethiopian and Kenyan samples), indicating the importance of the quality of as well as the access to extension services as perceived by farmers.

\section{Plot characteristics}

In three of the four countries, respondents who regarded their plot as having medium or good fertility were more likely to practice MTM. However, this may be because those who manage their plots well are also likely to experiment with new methods such as MTM. In Malawi on the other hand, those who viewed their plot as having 'good' fertility were less likely to adopt MTM. In a FAO (2001) study, it was reported that soil erosion and other soil-degradation indicators were positively associated with adoption of minimum tillage (Stonehouse 1991), and as reported by Uri (1997), there was evidence that plots with low levels of fertility were the ones where minimum tillage was likely to be adopted. The cited literature and our results suggest that the relationship between MTM adoption and plot quality is not uni-directional (see Malawi results) and that in some cases, farmers may be more likely to adopt MTM as a land-improvement practice on plots that they deem to have good potential for crop production, or that they may refrain from investing in the maintenance of poor plots they perceive to have low returns to such efforts. Therefore, the direction of the relationship between perceived quality or fertility of the plot and MTM adoption is clearly context specific and difficult to predict a priori.

\section{Physical capital and livestock assets}

As expected, the more livestock was available, the less likely was MTM to have been adopted in any of the household's plots. Although the sign is negative in all cases, as expected, the result is only significant in Ethiopia (a livestock-abundant system). The more non-livestock assets the household possessed, the more likely they were to have adopted MTM. This result was consistently significant across all country samples. This confirms the centrality of assets as an overriding determinant of MTM adoption if complementary practices such as seeding on an untilled or minimally tilled seedbed are to be implemented. It also suggests the importance of endowments generally, which is partly captured in the non-livestock asset variable.

\section{Social capital}

The more traders the household head reported knowing, the less likely he/she was to have adopted MTM in Ethiopia and Tanzania. This appears to indicate that those already having a strong market orientation (having interactions with or knowing many traders) and already intensifying their production by using higher amounts of fertilizer 
and having more successful farms may find the opportunity costs of the experimentation and adaptive process needed for new agricultural practices to be too high and therefore fail to commit to adopting them. Those who belonged to a farm association were more likely to have adopted MTM. Although the results are not similar in all cases, the positive association and ability to find support from non-relatives suggest the influence of social connectivity as a predictor of agricultural technology adoption through information or resource flows and other mutual support systems.

\section{Results from policy simulations}

In this section, we present the results of five simulations involving extension-to-farmer ratio and subsidy expenditure as a percentage of agricultural budgets. The aim is to test how an increase in these two indices would affect the predicted probability of adoption all else being equal. As explained in the section above that describe the policy variables, this is followed by varying the level of the other policy as well as that of credit availability. The five policy simulation results are as follows (See also Appendix Tables 3 and 4):

1a)Increasing the individual country's extension-to-farmer ratio (EFR) to Ethiopian level: The first simulation of the impact of EFR on the predicted probability of CA adoption is reported in Fig. 2. In Kenya, the probability of adoption increases from 3.9\% (base level) to 6.5\% when EFR is increased from 10 to 16 (Ethiopian level).

Similarly, in Malawi and Tanzania, the probability of adoption increased from about 3.4 to about 5\%, and in Tanzania from 10 to $21.4 \%$.

1b)Reducing extension (EFR) but increasing subsidies (SER) instead: In Fig. 2, we report simulation results of what would happen if the extension were reduced (by setting the EFRs of the other three countries at Tanzanian level) and SER simultaneously increased to Malawi's rate of 58.9. The results suggest the powerful impact of subsidy expenditure on the probability of adoption; despite reducing EFR in Ethiopia by 75\%, the probability of adoption increased by approximately $4 \%$ (from 26 to 30\%). The

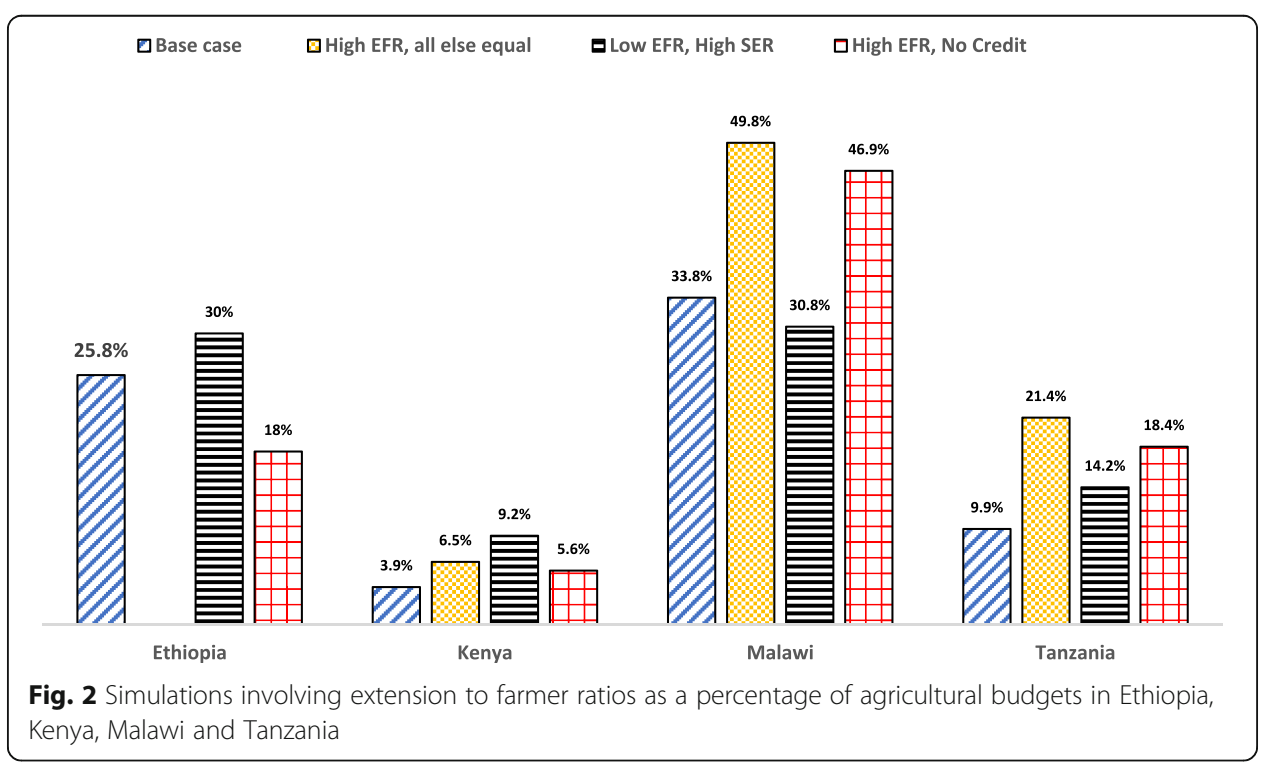


result for Malawi provides a 'counterfactual' in this case. When the SER remained the same and the EFR was reduced to Tanzanian level, the probability of adoption reduced in Malawi's case from about 34 to 31\%. For the other three countries' simulations, the increased SER appears to more than compensate for the reductions in EFR, so that probability of adoption increases despite reductions in EFR (Fig. 2).

1c)Increasing extension (EFR) with no credit availability: In these simulations (Fig. 2), the compensatory effect of high extension with a lack of credit is demonstrated. This was achieved by setting the EFR at the highest (Ethiopian) level and making credit unavailable for all (100\%) of the farmers. The results show that in all cases (except Ethiopia), predicted adoption increased from base levels by approximately $2 \%$ in Kenya, 13\% in Malawi and 9\% in Tanzania. The decrease in the probability of adoption in Ethiopia provides a useful benchmark for demonstrating the effect of credit constraint on the probability of adoption: the likelihood of adoption fell from 26 to $18 \%$ when all the households did not have credit. In the other three countries, the lack of credit was somewhat compensated for by an increase in EFR, while in the Ethiopian simulation, the EFR remained unchanged as credit availability was eliminated. These results indicate that increases in the reach of extension systems and availability of information can make up for lack of credit in fostering some level of adoption even though in themselves, these effects are modest, independent of other factors.

2a)Changing an individual country's input subsidies (SER) to Malawian level: In Fig. 3, the results show that setting SER at the Malawian level increases probability of adoption by more than $100 \%$ in Ethiopia (from 26 to $57 \%$ ) and Kenya (from 4 to $14 \%$ ) and by about $40 \%$ in Tanzania (10 to 14\%). These strong and significant impacts of SER and the earlier reported results for EFR are indicative of the potential that still exists for better information delivery and cost reduction in encouraging MTM adoption.

2b)Increasing subsidies (SER) with no credit availability: In the simulations that assumed no credit was available, but with a compensatory increase in subsidy at the highest (Malawian) level (also Fig. 3), the probability of adoption increased in all cases except in Malawi where credit availability was eliminated but SER was unchanged,

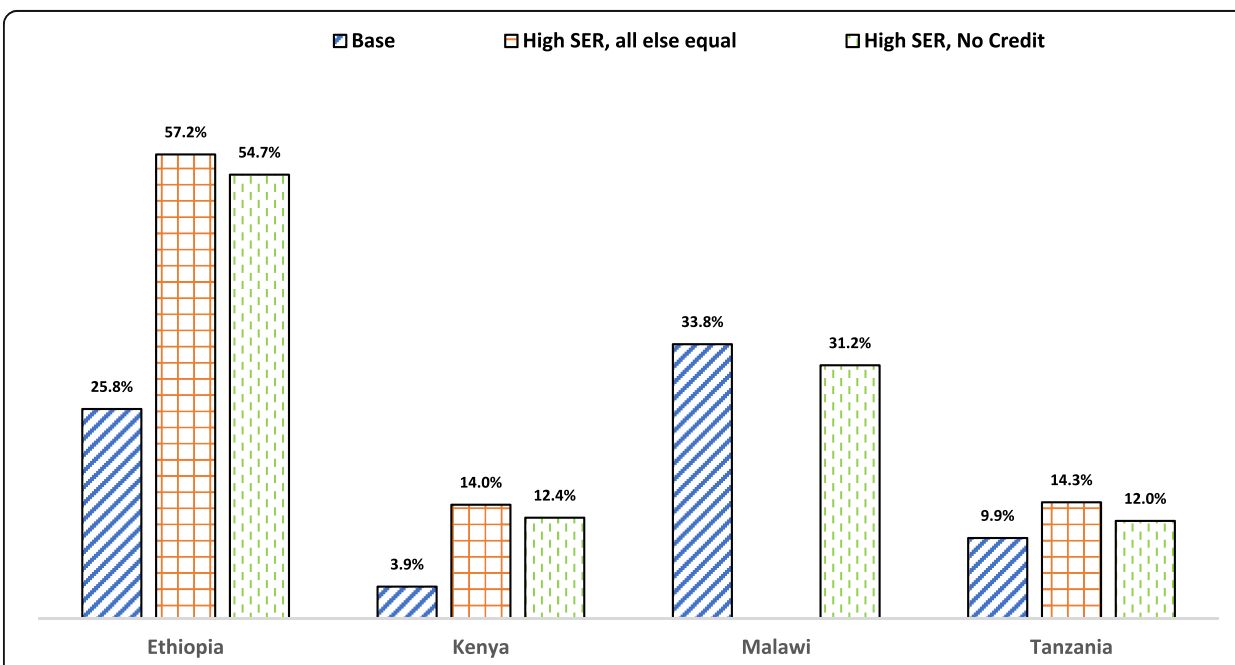

Fig. 3 Simulations involving subsidy expenditures as a percentage of agricultural budgets in Ethiopia, Kenya, Malawi and Tanzania 
leading to a reduction in probability of adoption from 34 to $31 \%$. The high levels of SER more than made up for the lack of credit. As a suggestion for policy or future research, a more specific policy would provide subsidies for the adoption of MTM, especially as the adoption of MTM can be considered to infer social benefits in terms of better environmental impacts such as soil loss mitigation and reduction of pollution from soil erosion.

\section{Conclusions}

In this paper, we set out to determine the impact of extension-personnel-to-farmer ratios and government expenditure on input subsidies in empirically predicting adoption of minimum tillage combined with mulching (MTM), controlling for household demographic, plot and market variables. From the probit results and subsequent simulations, we find that the likelihood of MTM adoption can be enhanced by a programme that supports farmers in acquiring inputs more cheaply (e.g. subsidies) and by increasing the extension-staff-to-farmer ratio. Generally, the results showed that both subsidy and extension can influence the probability of MTM adoption. When the extension-personnel-tofarmer ratios were compared to public expenditure on subsidies, the effect of the subsidy variable appears to have had the stronger effect on MTM adoption. When expenditure on subsidies as a percentage of total agricultural budgets was reduced, and extension-tofarmer ratio was increased, the probability of adoption fell. Granted, these results may be contingent on the ranges of simulation values used in this study and are tentative to this extent. For example, our data do not provide evidence on the quality or content of extension services. The simulation results as well as those from the regressions analysis nevertheless point to the conclusion that the challenges of MTM adoption and diffusion are similar to (if not the same as) those that face other agricultural technologies in general. These include resource availability, market access and social capital.

The implications of these results are twofold; firstly, the positive effect of input subsidies in increasing the probability of MTM adoption implies that MTM adoption takes place in the context of complementary inputs and that lowering the cost of these complementary inputs can help encourage farmers to try out new methods of production such as MTM. However, subsidies specifically targeted at MTM could also be considered, rather than assuming that MTM would indirectly benefit from fertilizer or seed subsidies. Farmers willing to comply with MTM and other environmentally beneficial farming practices could be eligible for such subsidies in recognition of the broader social benefits of these practices. Secondly, investing in agricultural extension systems by increasing the extension-personnel-to-farmer ratio is a crucial element in the success of MTM. The attention of policies for the upscaling of MTM should remain focused on the solid delivery of information through strong public and private agricultural extension services, on better access to markets and on the provision of inclusive finance as alternatives to subsidies.

While this study provides important evidence of the relative importance of two critical policy variables for agricultural development, we recognize one limitation as being the use of cross-sectional data and simulations. We recommend an improvement to this study that could involve collecting data using economic field experiments and randomized control trials to test the actual implementation of extension and subsidies and their impact on the adoption of MTM or other technologies of interest. Finally, a 
limitation of our analysis is that the observed use of MTM cannot be definitively described as long-term adoption or temporary trials by the farmer. More long-term and panel data sets are needed to make improvements on this issue. Therefore, similar policy-simulation studies may benefit more from panel data sets and models that capture crucial dynamic aspects not readily apparent in cross-sectional data analysis.

\section{Endnotes}

${ }^{1}$ See FAO (2001) for a detailed discussion of the three components of conservation agriculture (minimum tillage, mulching and crop associations) as well as the key economic considerations.

${ }^{2}$ In this paper, adoption is defined as observing MTM on a particular plot at the time of data collection. We do not have data on previous or subsequent use to make judgments on sustained adoption.

${ }^{3}$ In this paper, minimum tillage with mulching (MTM) refers to the specific combination of the two component technologies that are the focus in this paper, whereas conservation agriculture is broader and includes crop rotation in addition to MTM.

${ }^{4}$ Southern Nations, Nationalities and Peoples

${ }^{5}$ We use 'probability of MTM adoption' as shorthand for the proportion of plots observed to have MTM on them.

\section{Appendix}

Table 4 Extension simulations

\begin{tabular}{llllllll}
\hline Predicted probability of CA adoption by sample & & & & & & \\
& Whole sample & Ethiopia & Kenya & Malawi & Tanzania \\
\hline Base case $(A)$ & $0.168^{* * *}$ & $0.258^{* * *}$ & $0.039^{* * *}$ & $0.338^{* * *}$ & $0.099^{* * *}$ \\
& $(0.004)$ & $(0.008)$ & $(0.004)$ & $(0.009)$ & $(0.008)$
\end{tabular}

Panel I: effect of changing Extension-Staff-to-Farmer-Ratio (EFR): for each country set EFR at Ethiopian level

$\begin{array}{llllll}\text { EFR at Ethiopian mean }(B) & 0.214^{* * *} & \text { NA } & 0.065^{* * *} & 0.498^{* * *} & 0.214^{* * *} \\ & (0.019) & & (0.013) & (0.067) & (0.057) \\ \text { Chi-square tests } A=B & 5.47^{* * *} & \text { NA } & 4.47^{* *} & 5.91^{* *} & 4.10^{* *} \\ \text { Elasticities of adoption with respect to EFR A to B } & 0.795 & \text { NA } & 1.111 & 0.284 & 0.387\end{array}$

Panel II: effect of low EFR and high subsidy (SER): for each country set EFR Tanzania's level and SER at Malawi's level

$\begin{array}{clllll}\text { At Tanzania's EFR and Malawi's SER (C) } & 0.213^{* * *} & 0.301^{* * *} & 0.092^{* * *} & 0.308^{* * *} & 0.142^{* * *} \\ & (0.023) & (0.037) & (0.029) & (0.014) & (0.019) \\ \text { Chi-square tests } A=C & 3.85^{*} & 1.31 & 3.60^{*} & 6.50^{*} & 5.62^{*} \\ \text { Panel III: effect of high EFR with low SER (keeping both } & \text { EFR and SER at Ethiopia's level) } & & \\ \text { At Ethiopia's EFR and Ethiopia's SER (D) } & 0.129^{* * *} & \text { NA } & 0.048^{* * *} & 0.201^{* * *} & 0.080^{* * *} \\ & (0.015) & & (0.006) & (0.047) & (0.015) \\ \text { Chi-square tests A }=D & 7.22^{* *} & 1.31 & 3.61^{*} & 7.89^{*} & 2.35\end{array}$

Panel IV: effect of high extension with complete absence of credit: for each country set credit constraint at 1 and EFR at Ethiopia's level

\begin{tabular}{lllllll} 
No credit available and EFR at Ethiopia's level $(E)$ & $0.192^{* * *}$ & $0.179^{* * *}$ & $0.056^{* * *}$ & $0.469^{* * *}$ & $0.184^{* * *}$ \\
& $(0.019)$ & $(0.022)$ & $(0.011)$ & $(0.067)$ & $(0.051)$ \\
Chi-square tests $A=E$ & 1.75 & $12.16^{* * *}$ & 2.33 & $4.04^{*}$ & $2.73^{*}$ \\
\hline
\end{tabular}


Table 5 Subsidy simulations

\begin{tabular}{lllllll}
\hline $\begin{array}{l}\text { Predicted probability of CA adoption by sample } \\
\text { SER level }\end{array}$ & Whole sample & Ethiopia & Kenya & Malawi & Tanzania \\
\hline Base Level $(A)$ & $0.168^{* * *}$ & $0.258^{* * *}$ & $0.039^{* * *}$ & $0.338^{* * *}$ & $0.099^{* * *}$ \\
& $(0.004)$ & $(0.008)$ & $(0.004)$ & $(0.009)$ & $(0.008)$
\end{tabular}

Panel I: effect of changing subsidy expenditure as a percentage of agricultural budgets spent on farm input subsidies (SER). Set SER at Malawi's level

$\begin{array}{llllll}\text { At Malawian mean }(C) & 0.319^{* * *} & 0.572^{* * *} & 0.140^{* * *} & \text { NA } & 0.143^{* *} \\ & (0.67) & (0.126) & (0.057) & & (0.019) \\ \text { Chi-square tests } A=B & 5.12^{* *} & 6.38^{* *} & 3.11^{*} & \text { NA } & 5.62^{* *} \\ \text { Elasticities of adoption with respect to SER A to B } & 1.194 & 0.261 & 1.233 & \text { NA } & 1.585\end{array}$

Panel II: effect of low subsidy with full credit availability: for each country set SER at Ethiopia's level and credit constraint at 0

$\begin{array}{cllllll}\text { At Ethiopia's SER and no credit constraint }(C) & 0.109^{* * *} & 0.285^{* * *} & 0.033^{* * *} & 0.119^{* * *} & 0.031^{* * *} \\ & (0.024) & (0.010) & (0.006) & (0.062) & (0.017) \\ \text { Chi-square tests } A=C & 6.15^{* *} & 19.3^{* * *} & 2.54 & 11.83^{* * *} & 17.93^{* * *}\end{array}$

Panel III: effect of high subsidy with no credit available: for each country set credit constraint at 1 and SER = at Malawi's level

\begin{tabular}{cllllll} 
At Malawi's SER and no credit available $(D)$ & $0.292^{* * *}$ & $0.547^{* * *}$ & $0.124^{* * *}$ & $0.312^{* * *}$ & $0.120^{* * *}$ \\
& $(0.064)$ & $(0.126)$ & $(0.052)$ & $(0.010)$ & $(0.017)$ \\
Chi-square tests $A=D$ & $3.80^{*}$ & $5.34^{*}$ & 2.61 & $20.96^{* * *}$ & 1.63 \\
\hline
\end{tabular}

\section{Abbreviations}

CA: Conservation agriculture; CIMMYT: International Maize and Wheat Improvement Center; EFR: Extension personnelto-farmer ratios; ESA: East and Southern Africa; MTM: Minimum tillage and mulching; SER: Subsidy expenditure as a percentage of agricultural budgets spent on farm input subsidies

\section{Acknowledgements}

This work was supported by the Australian Centre for International Agricultural Research (ACIAR) through the International Maize and Wheat Improvement Center (CIMMYT)-led Sustainable Intensification of Maize-Legume Cropping Systems in Eastern and Southern Africa (SIMLESA) program under Grant CSE/2009/024 and Adoption Pathways Project under Grant FSC/2012/024 and International Fund for Agricultural Development (IFAD) under Grant COFIN-ECG-54-CIMMYT. We gratefully acknowledge additional financial support from the CGIAR program on MAIZE (CRP MAIZE). The views expressed here are those of the authors and do not necessarily reflect the views of ACIAR, IFAD or CIMMYT. We are solely responsible for any errors in this paper. The authors wish to thank two anonymous reviewers for helpful comments on a previous version of this paper.

\section{Authors' contributions}

PM conceptualized the paper and its methods and coordinated the write up and data analysis with the other four authors. MK and MJ coordinated data collection and curation. All the authors (PM, MK, MJ, DR and OE) participated in the writing of various sections of this paper and reviewed and contributed to the interpretation of results. All versions were reviewed and approved by all authors.

\section{Competing interests}

The authors declare that they have no competing interests.

\section{Publisher's Note}

Springer Nature remains neutral with regard to jurisdictional claims in published maps and institutional affiliations.

\section{Author details}

${ }^{1}$ International Maize and Wheat Improvement Center (CIMMYT), P.O. Box 5689, Addis Ababa, Ethiopia. ${ }^{2}$ International Centre of Insect Physiology and Ecology (ICIPE), Nairobi, Kenya. International Maize and Wheat Improvement Center (CIMMYT), El Batan, Mexico, D.F., Mexico.

Received: 25 January 2016 Accepted: 1 June 2017

Published online: 21 June 2017

\section{References}

ACT (2008) Linking production, livelihoods, and conservation. In: Proceedings of the Third World Congress on Conservation Agriculture. African Conservation Tillage Network, Nairobi, 3-7 October, 2005

Bishop-Sambrook C, Kienzle CJ, Mariki W, Owenya M, Ribeiro F (2004) Conservation agriculture as a labour saving practice for vulnerable households. FAO, Rome 
Daniel E (2013) Assessment of agricultural extension services in Tanzania. A case study of Kyela, Songea Rural and Morogoro Rural Districts, Internship Report. Wegeningen University, Wageningen

Davis K, Swanson B, Amudavi D, Mekonnen DA, Flohrs A, Riese J, Lamb C, Zerfu E (2010) In-depth assessment of the public agricultural extension system of Ethiopia and recommendations for improvement, Discussion Paper No. 01041. International Food Policy Research Institute (IFPRI), Washington DC

Dorward A, Chirwa E (2010) Evaluation of the 2008/9 agricultural input subsidy Malawi: notes on regression analysis of maize production. School of Oriental African Studies (SOAS), London

Ekboir J (2010) Learning organizations that support innovation: Mexico's produce foundations. In World Bank (ed) Agricultural Innovation Systems: An Investment Sourcebook. World Bank, Washington DC

Erenstein O (1999) The economics of soil conservation in developing countries: The case of crop residue mulching. Wageningen University, Wageningen

Erenstein O (2003) Smallholder conservation farming in the tropics and sub-tropics: a guide to the development and dissemination of mulching with crop residues and cover crops. Agric Ecosyst Environ 100(1):17-37

Erenstein O, Thorpe W (2010) Crop-livestock interactions along agro-ecological gradients: a meso-level analysis in the Indo-Gangetic Plains, India. Environ Dev Sustain 12(5):669-689

Erenstein O, Sayre K, Wall P. Hellin J, Dixon J (2012) Conservation agriculture in maize-and wheat-based systems in the (sub) tropics: lessons from adaptation initiatives in South Asia, Mexico, and Southern Africa. J Sustain Agric 36(2):180-206

FAO (2001) The economics of conservation agriculture: land use and water development. FAO, Rome

FAO (2012) Voluntary guidelines on the responsible governance of tenure of land, fisheries and forests in the context of national food security. FAO, Rome

FAO (2013) Climate smart agriculture: sourcebook. Food and Agriculture Organization of the United Nations, Rome

Fowler R, Rockstrom J (2001) Conservation tillage for sustainable agriculture: an agrarian revolution gathers momentum in Africa. Soil Tillage Res 61(1-2):93-107

Giller KE, Witter E, Corbeels M, Tittonell P (2009) Conservation agriculture and smallholder farming in Africa: the heretics' view. Field Crop Res 114(1):23-34

Government of Kenya (2012) National agricultural sector extension policy (NASEP). Government of Kenya, Nairobi

Hobbs PR (2007) Conservation agriculture: what is it and why is it important for future sustainable food production? J Agric Sci (Camb) 145(2):127

Hobbs PR, Sayre K, Gupta R (2008) The role of conservation agriculture in sustainable agriculture. Philos Trans R Soc Lond B Biol Sci 363(1491):543-555

Jack BK (2013) Constraints on the adoption of agricultural technologies in developing countries: literature review, Agricultural Technology Adoption Initiative, J-PAL (Massachusetts Institute of Technology) and CEGA (University of California, Berkeley)

Jaleta M, Kassie M, Shiferaw B (2013) Tradeoffs in crop residue utilization in mixed crop-livestock systems and implications for conservation agriculture. Agric Syst 121:96-105

Jaleta M, Kassie M, Erenstein O (2015) Determinants of maize stover utilization as feed, fuel and soil amendment in mixed crop-livestock systems, Ethiopia. Agric Syst 134:17-23

Jayne TS, Rashid S (2013) Input subsidy programs in sub-Saharan Africa: a synthesis of recent evidence. Agric Econ 44(6):547-562

Kaczan D, Arslan A, Lipper L (2013) Climate-Smart Agriculture? A review of current practice of agroforestry and conservation agriculture in Malawi and Zambia, ESA Working Paper No. 13-07. FAO, Rome

Kahimba FC, Mutabazi KD, Tumbo SD, Masuki KF, Mbungu WB (2014) Adoption and scaling-up of conservation agriculture in Tanzania: case of Arusha and Dodoma regions. Nat Resour 5(4):161

Kaizzi CK, Ssali H, Nansamba A, Vlek P (2002) The potential, and benefit of velvet bean (mucuna pruriens) and inorganic $\mathrm{N}$ fertilizers in improving maize production under soils of different fertility, Policy workshop, 17-19, April 2002 Africana Hotel, Kampala Uganda. Mimeo, Centre for Development Research (ZEF) University of Bonn, Germany

Kassie M, Teklewold H, Jaleta M, Marenya P, Erenstein O, Mekuria M (2014) Conservation agriculture and improved maize varieties adoption impact on crop income and input use: empirical evidence from Malawi. CIMMYT, Nairobi

Kassie M, Hailemariam T, Moti J, Marenya P, Erenstein O (2015) Understanding the adoption of a portfolio of sustainable intensification practices in eastern and southern Africa. Land Use Policy 42:400-411

Kherallah M, Delgado C, Gabre-Madhin E, Minot E, Johnson M (2002) Reforming agricultural markets in Africa. Johns Hopkins University Press, Baltimore

Knowler D, Bradshaw B (2007) Farmers' adoption of conservation agriculture: a review and synthesis of recent research. Food Policy 32(1):25-48

Lipper L, Thornton P, Campbell BM, Baedeker T, Braimoh A, Bwalya M, Caron P, Cattaneo A, Garrity D, Henry K, Hottle R (2014) Climate-smart agriculture for food security. Nat Clim Chang 4(12):1068-1072

Magnan N, Larson DM, Taylor JE (2012) Stuck on stubble? The non-market value of agricultural byproducts for diversified farmers in Morocco. Am J Agric Econ 94:1055-1069

Marenya PP, Barrett CB (2007) Household-level determinants of adoption of improved natural resources management practices among smallholder farmers in western Kenya'. Food Policy 32:515-536

Marietha Z, Wilfred LM, Josef K, Theodor F, Amir K (2011) Conservation agriculture (CA) in Tanzania: the case of the Mwangaza B CA farmer field school (FFS), Rhotia Village, Karatu District, Arusha. Int J Agric Sustain 9(1):145-152

Masangano C, Mthinda C (2012) Pluralistic extension system in Malawi. International Food Policy Research Institute (IFPRI) Discussion Paper No. 01171. IFPRI, Washington DC

Matsumoto T, Plucknett DL, Mohamed K (2004) Evaluation of the Sasakawa Global 2000 program in Ethiopia, 19922002. Sasakawa Africa Association, Addis Ababa

Milder JC, Majanen T, Scherr SJ (2011) Performance and potential of conservation agriculture for climate change adaptation and mitigation in sub-Saharan Africa, Ecoagriculture Discussion Paper no. 6. Ecoagriculture Partners, Washington, DC

Mloza-Banda HR (2002) Development and application of conservation agriculture in Malawi's smallholder subsistence and commercial farming systems. In: Mloza-Banda HR, Kumwenda WF, Manda M, Bwalya, M (eds) Conservation farming for sustainable agriculture workshop proceedings, Lilongwe, Malawi, 20-24 October 2002. 
Munthali MW, Kazombo Phiri SFM, Saka AR (2008) Socioeconomic factors affecting the adoption of soil and water conservation technologies among smallholder farming communities in Malawi. In: Nhira C, Mapiki A, Rankhumise P (eds) Land and water management in Southern Africa, Towards sustainable agriculture. African Institute, Pretoria

Muyanga M, Jayne TS (2006) Agricultural extension in Kenya: practice and policy lessons, Tegemeo Working paper 26/ 2006. Tegemeo Institute of Agricultural Policy and Development, Egerton University, Nairobi

Ndiritu SW, Kassie M, Shiferaw B (2014) Are there systematic gender differences in the adoption of sustainable agricultural intensification practices? Evidence from Kenya. Food Policy 49:117-127

Ngwira AR, Aune JB, Mkwinda S (2012) On-farm evaluation of short term yield and economic benefit of maize-legume intercropping systems under conservation agriculture in Malawi. Field Crop Res 132:149-157

Ngwira AR, Thierfelder C, Lambert DM (2013) Conservation agriculture systems for Malawian smallholder farmers: longterm effects on crop productivity, profitability and soil quality. Renewable Agric Food Syst 28(4):350-363

Ngwira A, Johnsen FH, Aune JB, Mekuria M, Thierfelder C (2014) Adoption and extent of conservation agriculture practices among smallholder farmers in Malawi. J Soil Water Conserv 69(2):107-119

Nyamangara J, Nyengerai K, Masvaya EN, Tirivavi R, Mashingaidze N, Mupangwa W, Dimes J, Hove L, Twomlow S (2014) Effect of conservation agriculture on maize yield in the semi-arid areas of Zimbabwe. Exp Agric 50(02):159-177

Pablo S, Precious G, Kelvin, Alexander L (2008) HIV/AIDS, climate change and disaster management: challenges for institutions in Malawi, Policy Research Working Paper

Pan L, Christiaensen L (2011) Who is vouching for the input voucher? World Bank Policy Research Working Paper 5651

Pannell DJ, Llewellyn RS, Corbeels M (2014) The farm-level economics of conservation agriculture for resource-poor farmers. Agric Ecosyst Environ 187:52-64

Peterman A, Quisumbing A, Behrman J, Nkonya E (2011) Understanding the complexities surrounding gender differences in agricultural productivity in Nigeria and Uganda. J Dev Stud 47(10):1482-1509

Pye-Smith C (2012) Agricultural extension, a time for change: linking knowledge to policy and action for food and livelihoods. Technical Centre for Agricultural and Rural Cooperation ACP-EU (CTA), Wageningen

Rivera WM, Alex G (2004) The continuing role of the public sector in pluralistic extension systems. In: Proceedings of the 20th Annual Conference of the Association for International Agricultural and Extension Education, April 2014 Miami, Florida.

Ryan JG, Spencer DC (2001) Future challenges and opportunities for agricultural R\&D in the semi-arid tropics. International Crops Research Institute for the Semi-Arid Tropics, Patancheru

Slavchevska V (2015) Gender differences in agricultural productivity: the case of Tanzania. Agric Econ 46(3):335-355

Smale M, Byerlee D, Jayne T (2011) Maize revolutions in sub-Saharan Africa, World Bank Development Group, Policy Research Working Paper, No. 5659. World Bank, Washington D.C

Stonehouse DP (1991) The economics of tillage for large-scale mechanized farms. Soil Tillage Res 20(2):333-351

The Royal Society (2009) Reaping the benefits. Science and the sustainable intensification of global agriculture, Royal Society Policy Document 11/09

Uri ND (1997) Conservation tillage and input use. Environ Geol 29(3/4):188-201

Valbuena D, Erenstein O, Tui SH, Abdoulaye T, Claessens L, Duncan AJ, Gérard B, Rufino MC, Teufel N, van Rooyen A, van Wijk MT (2012) Conservation agriculture in mixed crop-livestock systems: scoping crop residue trade-offs in sub-Saharan Africa and South Asia. Field Crop Res 132:175-184

Yanggen D, Kelly V, Reardon T, Naseem A (1998) Incentives for fertilizer us in sub-Saharan Africa: a review of empirical evidence on fertilizer response and profitability, University International Development Working Paper No. 70. Michigan State University, East Lansing

\section{Submit your manuscript to a SpringerOpen ${ }^{\circ}$ journal and benefit from:}

- Convenient online submission

- Rigorous peer review

Open access: articles freely available online

High visibility within the field

- Retaining the copyright to your article

Submit your next manuscript at $\gg$ springeropen.com 